\title{
Aktivitetsplikt for sosialhjelpsmottakere - har lovgiveren funnet opp hjulet på nytt?
}

\author{
Aina A. Kane og Julia Köhler-Olsen
}

Regjeringens begrunnelse for lovendringen som medfører at det skal stilles vilkår om aktivitet ved tildeling av økonomisk sosialhjelp, er at en slik aktivitetsplikt anses som den beste måten å bistå søkerne med overgang til arbeidslivet. Vår empiriske unders økelse viser at regjeringens forutsetning for å endre regelen er for svakt begrunnet fordi det i praksis er tilgangen til et tilstrekkelig antall aktiviteter som er en av de viktigste faktorene for å fremme overgang til arbeid. Aktivitetene må dessuten være hensiktsmessige. Videre kreves det at det finnes ressurser til kartlegging og oppfølging av den enkelte. Tilbudet må også baseres på en forståelse av at særlig unge sosialhjelpsmottakere er en risikoutsatt gruppe hvor mange har en vanskelig bakgrunn. Forfatterne gir en grundig analyse av lovens ordlyd og oppbygning etter endringen og viser at lovteksten slik den nå fremstår utydeliggjør disse viktige faktorene og gir inntrykk av en snevert moraliserende tilnærming til problemet

\section{Innledning}

Lovgiver har ved lov av 24. april 2015 nr. 20 (ikke i kraft) endret lov om sosiale tjenester i arbeids- og velferdsforvaltningen av 18. desember $2009 \mathrm{nr} 131$ (sosialtjenesteloven, sostl) $\S$ 20 første setning, slik at sosialtjenesten i Nav ikke lenger bare kan, men skal stille vilkår om aktivitet for tildeling av økonomisk stønad med mindre tungtveiende grunner taler mot det. Formålet er å fremme overgangen fra å være sosialhjelpsmottaker til å bli arbeidstaker ${ }^{1}$, jfr også formålsbestemmelsen i sostl $§ 1$. Vedtaket om å innføre denne aktivitetsplikten kombineres med et nytt tredje avsnitt i § 20 om sanksjonering ved at økonomisk stønad kan reduseres for mottakere som ikke oppfyller plikten. Departementet kan gi nærmere regler om dette.

Rundt 125000 var registrert som sosialhjelpsmottakere for året $2014 .^{2}$ Til sammenligning mottok i 2013 rundt 1,7 millioner personer ulike stønader fra folketrygden. ${ }^{3}$ Det kan gi grunn til å spørre hvorfor lovgiveren nå gir særlige regler om plikt til å knytte slike tyngende vilkår

\footnotetext{
${ }^{1} \mathrm{Se}$ https://www.regjeringen.no/no/tema/pensjon-trygd-og-sosiale-tjenester/innsikt/sosiale-tjenester/okonomisksosialhjelp/aktivitetsplikt-for-mottakere-av-sosialhjelp/id2009224/ [sitert 17.11.2015]

${ }^{2}$ Se https://www.ssb.no/sosiale-forhold-og-kriminalitet [sitert 17.11.2015]

${ }^{3} \mathrm{Se}$ https://www.Nav.no - tallene for 2014 foreligger ikke per november 2015 [sitert 17.11.2015]
} 
til en ytelse som representerer en forholdsmessig beskjeden del av de offentlige utgifter til kompensasjon av inntektsbortfall. Utgiften til slik stønad har $\emptyset \mathrm{kt}$ med fire prosent i $2014 \mathrm{og}$ nesten tilsvarende i 2012 og i 2013. Her er det også et poeng at arbeidsrettede tiltak utgjør en forholdsvis liten andel av sosialsektorens driftsutgifter, nærmere bestemt seks prosent av de samlede utgiftene for sosialsektoren i 2014. ${ }^{4}$ Denne lave andelen, sammen med $\varnothing$ kende utgifter innenfor sosialsektoren generelt, taler for at det bør være rom for mer bruk av arbeidsrettede tiltak enn det som gjøres i dag. Regjeringen kan vise til kommuner som har hatt gode resultater av å anvende slik aktivitetsplikt. Åmli kommune i Aust-Agder viste til at de hadde redusert sosialhjelpsutgiftene sine med $90 \%$ de siste ti år, og begrunnet sitt resultat med at kommunen prioriterer tett oppfølging, $\varnothing$ konomisk veiledning og tydelige krav. ${ }^{5}$ Fjell kommune i Hordaland viste at de gjennom bedre og tettere oppfølging av den enkelte brukeren ut fra målet om at brukerne skal over fra sosialhjelp til eget arbeid, har fått om lag $60 \%$ av deltakerne på kommunens arbeidsopplegg ut i ordinært arbeid eller andre arbeidsrelaterte opplegg. ${ }^{6}$ Når slike resultater kunne oppnås innenfor gjeldende lovgivning åpner det for spørsmålet om hvorvidt lovgivningen ikke har vært tydelig nok på adgangen til å pålegge stønadsmottakerne hensiktsmessige arbeidsrettede aktiviteter, eller om det $\mathrm{i}$ alle fall er nødvendig å bruke sterkere virkemidler for å få kommunene til å prioritere sterkere bruken av dette virkemidlet. Kommunenes forbruk på kun seks prosent av sosialbudsjettet til arbeidsrettede tiltak sammenlignet med enkeltkommuner som Fjell og Åmli gir grunn til å stille spørsmål om hvorfor kommunene anvender dagens adgang til å stille vilkår om aktivitet i slik varierende grad.

Med bakgrunn i disse spørsmålene er ett av formålene for vårt arbeid å klargjøre rettsgrunnlaget for å stille vilkår om aktiviteter samt rammene for Navs skjønnsutøvelse i individuelle saker. Ytterligere formål er å gi et empirisk grunnlag for å

1) slå fast hvordan dagens hjemmel for vilkår ved sosialhjelp blir forstått i praksis,

2) ta stilling til holdbarheten av den faktiske premiss om virkemiddelet som den nye lovendringen baserer seg på, og

3) sette et kritisk søkelys på lovens ordlyd etter lovendringen ut fra lovens formål og lovens forarbeider, samt gi en anbefaling til hvordan regelverket kan utformes og praktiseres i

\footnotetext{
${ }^{4} \mathrm{Se}$ https://www.ssb.no/sosiale-forhold-og-kriminalitet/statistikker/soshjelpk/aar/2015-07-06 [sitert 17.11.2015]

${ }^{5} \mathrm{Se}$ http://www.hoyre.no/Aktuelt/Arkiv/Aktivitetsplikt-for-alle-sosialhjelpsmottakere [sitert 17.11.2015]

${ }^{6} \mathrm{Se}$ https://www.regjeringen.no/no/aktuelt/Vil-bruke-Muligheten-som-mal/id757465/ [sitert 17.11.2015]
} 
fremtiden for å oppnå den målsettingen som regelverket bygger på, blant annet for å unngå uheldige bieffekter.

På denne bakgrunnen har vi gjort en empirisk analyse, med den overordnede problemstilling: Hvordan kan en innføring av individuell aktivitetsplikt fremme eller hemme overgang fra sosialhjelp til arbeid?

Et delmål for vårt arbeid med den empiriske undersøkelsen er å få svar på hvilke konsekvenser bruk av tilbud om arbeidsrettede tiltak til sosialhjelpsmottakere får. Dersom konsekvensene av å tilby arbeidsrettede aktiviteter i all hovedsak er positive, vil dette i utgangspunkt støtte regjeringens forslag om å lovfeste en individuell aktivitetsplikt for alle sosialhjelpsmottakere. Men dette gjelder bare så langt det kan sannsynliggjøres at kommunene bruker dette virkemiddelet i altfor liten grad. Dersom dagens lovregulering fungerer etter sitt formål om å få flere over fra sosialstønad til arbeid, taler det for at det kan være ikke bare unødvendig, men direkte uheldig å endre loven. Den fleksibiliteten som dagens lovgivning muliggjør i det sosialfaglige arbeidet med klienten, vil bli innskrenket når det innføres en plikt til å stille vilkår om deltakelse i aktivitet ved tildeling av stønad til livsopphold. Det er klart problematisk ut fra lovens institusjoner om hjelp til selvhjelp hvis slik plikt pålegges nærmest mekanisk, uten en foregående dialog med brukeren der hun/han opplever dette som en meningsfylt hjelp til å komme ut av en vanskelig livssituasjon.

\section{Fremgangsmåte og metodiske valg}

For å kunne svare på konsekvensene av den tidligere og dagens lovregulering om arbeidsrettede tiltak er det nødvendig å ta utgangspunkt i forståelsen og praktiseringen av dagens lovregulering. Utgangspunktet er tolkningen av loven ut fra de autoritative juridiske kildene ut fra etablerte tolkningsprinsipper, med fokus på å komme frem til en forståelse av regelverket som fremstår som den mest «forsvarlige». ${ }^{7}$ Den rettslige forståelsen som danner grunnlaget for dagens praksis skal analyseres i punkt 3 og 4 i artikkelen. Vi ønsket så innsikt i hvilke erfaringer ansatte i Nav sosialtjeneste har med å anvende sosialtjenesteloven i sitt

\footnotetext{
${ }^{7}$ Henriette Sinding Aasen, Pasientens rett til selvbestemmelse ved medisinsk behandling, Bergen 2000 s. 124. Julia Köhler-Olsen, Barns rett til selvbestemmelse i forhold til religiøse normer, Oslo 2012 s. 21 . Forfatterne omtaler tolkningsprosessen slik at den bør lede frem til den mest forsvarlige avgjørelsen. Om bruk av autoritative kilder i den juridiske metoden, se nærmere på Aleksander Pezcenic, Vad är rätt?, Stockholm 1995, Stig Strömholm, Rätt, rättskällor och rättstillämpning : En lärobok i allmän rättslära, Stockholm 1996, og Thorstein Eckhoff og Jan E. Helgesen, Rettskildelaere, Oslo 1997.
} 
arbeid med sosialhjelpsmottakere, herunder lovens adgang til å pålegge aktivitetstilbud. Dessuten $\emptyset$ nsket vi deres vurderinger av behovet for lovendringen om aktivitetsplikt. For å innhente denne informasjonen kontaktet vi et tilfeldig utvalg av tolv Nav-kontorer med store geografiske og demografiske variasjoner, i henholdsvis nordlige og sør-østlige områder. For hvert kontor ba vi om intervju med en ansatt med ansvar for saksbehandling av søknader om $\emptyset$ konomisk stønad, slik at vi intervjuet seks hver. Samtlige ansatte var sosialarbeidere med ulike etter- og videreutdanninger og ulik fartstid i Nav. Vi avgrenset målgruppen til å handle om de unge sosialhjelpsmottakerne (18-30 år), begrunnet i politikernes fokus på nettopp denne målgruppen i media. En delvis strukturert intervjuguide ga rom for saksbehandlernes refleksjoner, kommentarer og erfaringer. Datamateriale fra tolv saksbehandlere fra tolv Navkontorer er ikke representativt for alle Nav-kontorer i landet, men deres informasjon kan likevel kaste lys over tendenser i forvaltningspraksisen, noe som kan sies å ha overføringsverdi i forhold til andre Nav-kontorer. Resultatene fra den empiriske unders $\varnothing$ kelsen gjengis og analyseres i punkt 5 i artikkelen.

\section{Stønad til livsopphold og adgangen til å pålegge deltakelse i arbeidsrelaterte aktiviteter}

\subsection{Kort om stønad til livsopphold}

Grunnvilkåret for stønad til livsopphold er at søkeren «ikke kan sørge for sitt livsopphold gjennom arbeid eller ved å gjøre gjeldende økonomiske rettigheter», jf. sostl. § 18. Ordlyden synliggjør at stønad til livsopphold skal forbeholdes søkere som på ingen måte har midler til å dekke nødvendige utgifter til sitt daglige liv; bolig, strøm, mat, klær, medisiner, transport og annet. Arbeidsinntekter skal etter ordlyden være den primære måten å forsørge seg selv på, eventuelt $\emptyset$ vrige egne midler, dernest andre $\varnothing$ konomiske rettigheter som for eksempel trygdeytelser. Økonomisk stønad etter sosialtjenesteloven skal derfor være det nederste sikkerhetsnettet for personer uten andre muligheter til å forsørge seg. En søker som oppfyller disse kriteriene, har rettskrav på stønad, jf. ordlyden «har krav på økonomisk stønad». Loven angir ikke stønadens størrelse, men bistanden skal etter sostl. $§ 4$ være forsvarlig. ${ }^{8}$ Samtidig

\footnotetext{
${ }^{8}$ Komiteen til ESC kritiserte Norge i sine avsluttende bemerkninger i 2013 for at størrelse på økonomisk stønad i Norge er «inadequate», dvs. for lave. 2013/def/NOR/13/1/EN - Norway - Article 13-1.
} 
sier sostl. $\S 18,2$. ledd at «stønaden bør ta sikte på å gjøre vedkommende selvhjulpen», i tråd med lovens formålsbestemmelse.

\subsection{Navs adgang til å stille vilkår om deltakelse i arbeidsrettede aktiviteter før og etter lovendringen}

Kommunens adgang til å stille vilkår ved tilståelse av økonomisk sosialhjelp fremgikk allerede av Lov om sosial omsorg 5. juni 1964 nr. 5, § 3 (3), 2. ledd. Adgangen ble videreført i Lov om sosiale tjenester 13. desember $1991 \mathrm{nr} .81 \S 5-3$, og deretter i sosialtjenesteloven av 2009, § 20, som har følgende ordlyd:

«Det kan settes vilkår for tildeling av økonomisk stønad, herunder at mottakeren i stønadsperioden skal utføre passende arbeidsoppgaver i bostedskommunen ..[..]..

Vilkårene må ha nær sammenheng med vedtaket. De må ikke være uforholdsmessig byrdefulle for stønadsmottaker eller begrense hans eller hennes handlefrihet på en urimelig måte».

I lovens forarbeider ble adgangen til å stille slike vilkår begrunnet med at stønad til livsopphold er en subsidiær ytelse i forhold til selvforsørgelse gjennom eget arbeid, fordi egenforsørgelse skal være målet. ${ }^{9}$ I forarbeidene til lov om sosiale tjenester av 1991, der den ulovfestede vilkårslæren ble lovfestet, kom det dessuten frem at adgangen til å stille vilkår rettet seg spesielt mot unge arbeidsledige stønadsmottakere som ikke hadde tilbud om arbeidsmarkedstiltak. Slike vilkår blir i forarbeidene eksemplifisert med passende oppgaver og/eller arbeid som er hensiktsmessige for arbeidstilvenning, herunder «deltakelse på arbeidsmarkedstiltak». ${ }^{10}$

Forarbeidene til sosialtjenesteloven av 2009 peker likeledes på arbeidsrettede tiltak som eksempler på relevante vilkår, herunder «deltagelse på arbeidsmarkedstiltak, kommunale kvalifiseringstiltak, aktiv jobbsøking eller om å akseptere et bestemt jobbtilbud». Adgangen til og begrunnelsen for å stille krav om at brukeren skal delta i arbeid/arbeidsrettede tiltak henger derfor sammen med formålene om overgang til arbeid, aktiv deltakelse i samfunnet, egenforsørging og selvstendighet. At et vilkår skal ha «nær sammenheng med vedtaket» betyr at det skal være en balanse mellom vedtaket om stønad til livsopphold og de(t) vilkår som

\footnotetext{
${ }^{9}$ Ot.prp. nr. 103 (2008-2009), pkt. 3.3.1.

${ }^{10}$ Innst. O. nr. 9 (1991-1992) s. 26-28.
} 
vurderes. Ut fra formålsbestemmelsene kan et vilkår om deltakelse i en aktivitet sies å være begrunnet i søkerens behov for arbeidsbistand, ved at søkerens stønadsbehov er begrunnet i at han/hun mangler jobb og inntekt. Vilkår for stønad til livsopphold skal ikke fremstå som sanksjonering og maktmisbruk, og heller ikke som urimelig byrdefulle for mottakeren. ${ }^{11}$

Etter endringen ved lov av 24. april 2015 og fra ikrafttredelsestidspunktet vil sosialtjenesteloven $\S 20$ første ledd ha følgende ordlyd:

«Det skal stilles vilkår om aktivitet for tildeling av økonomisk stønad med mindre tungtveiende grunner taler mot det. Det kan også stilles andre vilkår for tildeling av $\varnothing$ konomisk stønad, inkludert vilkår etter $§ 25 »$.

Ordlyden i første setning viser at vilkårsstillelse om en eller flere aktiviteter normalt blir en forutsetning for å treffe vedtak om økonomisk stønad. Sett i sammenheng med grunnvilkåret i sostl. § 18 om at søkeren «ikke kan sørge for sitt livsopphold gjennom arbeid eller ved å gjøre gjeldende økonomiske rettigheter», fremstår vilkår om aktivitet som enda ett tilleggsvilkår for $\emptyset$ konomisk stønad. Denne forståelsen understrekes av at unntak fra aktivitetsplikten knyttes til «tungtveiende grunner», altså en snever adgang til å unnta en søker fra aktivitetsplikten for å motta $\varnothing$ konomisk stønad. Med grunnlag i den snevre unntaksadgangen er det mulig å omtale plikten til aktivitet som en universell aktivitetsplikt.

Det følger av forarbeidene at plikten til å stille vilkår knytter seg til aktivitet med sikte på overgang til ordinært arbeid eller utdanning. Formålet med forslaget om aktivitetsplikt er således å bidra til at flere kommer over i arbeid og blir selvforsørget. For å unngå misforståelsen om at andre type vilkår enn arbeidsrettede aktiviteter ikke lenger kan stilles, har lovgiveren tatt inn i den nye $\S 20$ første ledd andre punktum en presisering om at det fortsatt er adgang til å stille andre typer vilkår. ${ }^{12}$

Departementet legger til grunn at arbeidsrettet aktivitet for de som er i stand til å delta, er et gode i seg selv og et virkemiddel for å komme over i arbeid og bli selvforsørget. ${ }^{13}$ Plikten til å være i aktivitet vil kunne hemme unødvendig passivisering av stønadsmottakerne og fremme arbeidslinja fremfor ingen aktivitet i det hele tatt. Forarbeidene til lovendringen fra 2015 viderefører individperspektivet knyttet til sosialstønad og tilhørende vilkår om aktivitet.

\footnotetext{
${ }^{11}$ Se også nedenfor punkt 4 om Norges menneskerettslige forpliktelser.

12 Prop. 39 L (2014-2015) pkt. 6.6.1 og 6.6.2.

${ }^{13}$ Prop. 39 L (2014-2015) pkt. 6.6.3.
} 
Aktiviteten skal være arbeidsrettet og meningsfull for den enkelte. ${ }^{14}$ Den pålagte aktiviteten skal dessuten være individuelt tilpasset den enkeltes behov og funksjonsnivå ${ }^{15} \mathrm{og}$ vurderingene skal fremgå av saksbehandlingens dokumenter. Videre uttaler forarbeidene at brukermedvirkning etter sostl. $\S 42$ fortsatt skal gjelde, og at det er viktig at stønadsmottakerens behov, synspunkter og ønsker tas med i vurderingen av om det skal stilles vilkår og hvilke aktiviteter det eventuelt skal kreves deltakelse i. ${ }^{16}$

Ifølge forarbeidene er ett av formålene med krav til aktivitet å gi legitimitet til velferdsytelsene gjennom en bedre balanse mellom rettigheter og plikter. Den enkeltes muligheter til å komme i jobb skal styrkes, og pliktene skal motivere for overgang til jobb ved at aktiviteten er arbeidsrettet og meningsfull for mottakeren. ${ }^{17}$ Hovedbegrunnelsen for lovforslaget er nettopp at dagens adgang til å stille vilkår om aktivitet i varierende grad blir anvendt $\mathrm{i}$ kommunene. Dersom tjenestemottakeren ikke følger opp et pålagt vilkår, må Nav vurdere hvorvidt dette skal sanksjoneres i form av stønadsreduksjon, med hjemmel i et nytt tredje ledd i sosialtjenesteloven $\S 20 .{ }^{18}$ En eventuell sanksjon kan uansett ikke innebære fullstendig stans i utbetaling dersom stønad til livsopphold er mottakerens eneste kilde til fors $\varnothing$ rgelse, jf. lovens $§ 18$. Til tross for at plikten til aktivitet er universell, viser forarbeidene til formålet om å styrke den enkeltes muligheter til å komme i jobb. Ovenfor har vi konkludert med at den snevre unntaksadgangen taler for at plikten til å stille vilkår innebærer en universell aktivitetsplikt for stønadsmottakere. Samtidig retter plikten seg ikke bare mot tilnærmet alle stønadsmottakere, men har også som siktemål den enkelte stønadsmottakerens nåværende $\mathrm{og}$ fremtidige livssituasjon. På bakgrunn av dette mener vi at lovendringen innebærer etableringen av en individuell og universell aktivitetsplikt.

Som en oppsummering kan vi ut fra de ovennevnte rettskilder konkludere med at Nav etter någjeldende sosialtjenestelov $\S 20$ har adgang til å stille vilkår om arbeidsrettede aktiviteter. Hvorvidt Nav har plikt til å tilby sosialhjelpsmottakere individuelt tilpassede og hensiktsmessige arbeidsrelaterte tiltak fremgår ikke eksplisitt av sosialtjenesteloven. Grunnloven $\S 110$ pålegger myndighetene å «legge forholdene til rette for at ethvert

\footnotetext{
${ }^{14}$ Prop. 39 L (2014-2015) punkt 6.6.2.

${ }^{15}$ Ibid.

${ }^{16}$ Ibid.

${ }^{17}$ Prop. 39 L (2014-2015) pkt. 6.1.

${ }^{18}$ Som nevnt under punkt 3 krever Komiteen til ESC at reduksjon eller stopp av sosialhjelp bare kan være i samsvar med Det europeiske sosialcharteret når det ikke fratar enkeltindividet livsgrunnlaget.
} 
arbeidsdyktig menneske kan tjene til livets opphold ved arbeid eller næring». Ut fra grunnlovsbestemmelsen samt sosialtjenestelovens formålsbestemmelse om bistand til overgang til arbeid og $\S 42$ om samarbeid med brukeren kan en implisitt hevde at Nav er forpliktet til å arbeide og samarbeide med den enkelte bruker om arbeidsrettede aktiviteter for at vedkommende skal komme ut av sosialhjelpssituasjonen.

\section{Overgang til arbeid som formål for sosialhjelp}

Arbeid er en kilde til forsørgelse og viktig faktor i forebygging og bekjempelse av fattigdom. Ifølge Frøyland og Spjelkavik bidrar deltakelse i arbeidslivet også til blant annet utvikling av kompetanse, livsglede, tilfriskning, sosialisering og tilhørighet. ${ }^{19}$ «Arbeid er selve nøkkelen ... det har så mange flere sider enn bare inntekt; selvstendighet, identitet, mestring og det å få tilbakemeldinger». ${ }^{20}$ «Arbeidslinja» som politisk styringsverktøy har et overordnet mål om høy sysselsetting og lav ledighet, jf. Prop. 130 L (2010-2011) s. 63. Gjennomføring av arbeidslinja som politisk mål er lagt til Arbeids- og velferdsetaten (Nav) jf. lov 16. juni 206 nr. 20 om arbeids- og velferdsforvaltningen (Nav-loven), og ifølge lovens $§ 1$ er dens formål å tilrettelegge for effektiv arbeids- og velferdsforvaltning, tilpasset både den enkelte bruker og arbeidslivets behov. Dette er i tråd med arbeidslinja i velferdspolitikken, som også ligger til grunn for eksempelvis arbeidsavklaring ${ }^{21} \mathrm{og} \mathrm{kvalifiseringsprogram}^{22}$. Likevel må arbeidslinja ses i forhold til målgruppen for de ulike tjenester, og de enkelte personers ressurser og behov.

Forarbeidene uttaler at Nav skal «motivere og bistå den enkelte stønadsmottakeren til arbeidsaktivitet der dette er mulig». ${ }^{23}$ Nav forvalter sosialtjenesteloven, jf. Nav-loven $§ 13,2$. ledd, og søknader om $\emptyset$ konomisk bistand saksbehandles og vedtas av sosialtjenesten i det enkelte Nav lokalkontor, jf. sostl. § 3, 1. ledd. Sosialtjenesteloven har, tilsvarende Nav-loven, formål om både å «bidra til økonomisk trygghet» og å «fremme overgangen til arbeid», jf. Nav-loven $\S 1$ og sostl. $§ 1$. I forarbeidene beskrives at «personer som av ulike årsaker har falt ut av eller ikke er kommet inn på arbeidsmarkedet, skal møte et offentlig tjenestetilbud som

\footnotetext{
${ }^{19}$ Kjetil Frøyland og Øystein Spjelkavik, «Inkluderingskompetanse - et integrert perspektiv», i Inkluderingskompetanse - ordinært arbeid som mål og middel. Oslo 2014 s. 18-32, s.19.

${ }^{20}$ Aina A. Kane, «Godt skjønn? Vilkår og skjønnsutøvelse i saker om arbeidsavklaringspenger og kvalifiseringsstønad» i Sosialfaglige utfordringer på nye arenaer - stemmer fra nord. Stamsund 2013 s. 225-251, s. 232.

${ }^{21}$ Lov 28. februar 1997 nr. 19 om folketrygd (folketrygdloven), kapittel 11.

${ }^{22}$ Lov 18. desember $2009 \mathrm{nr} .131$ om sosiale tjenester i arbeids- og velferdsforvaltningen (sosialtjenesteloven), kapittel 4.

${ }^{23}$ Ot.prp. nr. 70 (2006-2007) til sosialtjenesteloven pkt. 3.2.1.
} 
kan yte rask og individuelt tilpasset bistand. Det følger av loven at kontoret skal samarbeide med andre tjenesteytere om planen». ${ }^{24}$ Oppsummert innebærer det at Nav, i tillegg til å bistå enkeltpersoner økonomisk, også skal bistå disse effektivt med overgang til arbeid og aktiv virksomhet, tilpasset den enkelte brukers og arbeidslivets behov. Det er et mål at bistandsmottakere skal komme raskest mulig ut i arbeid og/eller arbeidsrettede tiltak, og bli selvforsørget.

Ifølge Grunnloven $§ 110$ første ledd første setning skal myndighetene, som nevnt, «legge forholdene til rette for at ethvert arbeidsdyktig menneske kan tjene til livets opphold ved arbeid eller næring». Videre fastslår den samme grunnlovsbestemmelsen i første ledd andre setning at «den som ikke selv kan sørge for sitt livsopphold, har rett til støtte fra det offentlige». Det er således statens plikt å tilrettelegge for at alle kan få seg en jobb. Dersom den enkelte av ulike grunner ikke kan skaffe seg en jobb, er setningen om sosial trygghet i Grunnloven § 110 ment å få frem at ytelser som trygd og sosialhjelp er subsidiære i forhold til arbeids- eller næringsinntekt. Den valgte formuleringen er knyttet opp til den enkeltes evne til å skaffe utkomme ved eget arbeid eller næring, ikke den enkeltes vilje. ${ }^{25}$ Når man leser Grunnloven § 110 første ledd første og andre setning i sammenheng, gir dette grunnlag for lovgiveren til å kunne tilrettelegge for at den enkelte sosialhjelpsmottakeren på kort eller lang sikt kan få seg en jobb gjennom å stille vilkår. Den mottakeren som imidlertid ikke viser vilje til å anvende sine evner for å skaffe seg arbeid- eller næringsinntekt, har ikke rett på støtte fra det offentlige.

Retten til arbeid og retten til sosialhjelp er i tillegg til nasjonal rett nedfelt i en rekke regionale og globale menneskerettighetsinstrumenter. ${ }^{26}$ Det europeiske sosialcharteret (ESC) har nedfelt retten til sosialhjelp i ESC artikkel 13 nr. 1. Komiteen til det europeiske Sosialrettscharter (European Committee of Social Rights, ECSR) har i sin generelle kommentar til ESC art. 13 om retten til sosialhjelp uttalt at det for medlemsstatene er adgang til å kreve at mottakeren av sosialhjelp søker arbeid eller utøver arbeidsrettet aktivitet. Det er imidlertid krevd at vilkårene er «reasonable and consistent with the aim pursued», som betyr at aktivitetene må være hensiktsmessige og ha som siktemål å løse individets problemer varig, i motsetning til for

\footnotetext{
24 Ibid.

${ }^{25}$ Dokument 16 (2011-2012) - Rapport fra Menneskerettsutvalget om menneskerettigheter i Grunnloven, 19. desember 2011, punkt 38.5.1 s. 231 og punkt 39.6.2.1 s. 240-241.

${ }^{26}$ Retten til arbeid finner vi blant annet i FNs menneskerettserklæring artikkel $23 \mathrm{nr}$. 1, i FN konvensjonen om økonomiske, sosiale og kulturelle rettigheter (ØSK) artikkel 6 og i det reviderte Europeiske Sosialcharter (ESC) artikkel 1, samt EUs charter om fundamentale rettigheter i Den europeiske Unionen (EUCFR) artikkel 15 nr. 1. For å sikre retten til arbeid er statene forpliktet til å føre en aktiv arbeidsmarkedspolitikk, jf. blant annet ØSK art. 6 nr. 2 og ESC art. 1 nr. 1, 3 og 4. Retten til sosialhjelp er omfattet av FNs menneskerettserklæring art. 25 nr.1, ØSK art. 11, ESC. Art. 13 nr. 1 og art. 30, samt EUCFR art. 34 nr. 3. Norge har ratifisert alle de nevnte menneskerettighetsintrumentene.
} 
eksempel et korrigerende eller oppdragende formål. ${ }^{27}$ I forbindelse med komiteens avsluttende bemerkninger til Norges rapport i desember 2013 minnes den norske staten på forpliktelsen om at vilkårene knyttet til utbetaling av sosialhjelp skal være hensiktsmessige og formålstjenlige. Kravet om at vilkår som stilles må være hensiktsmessige og formålstjenlige innebærer at arbeidsrettede aktiviteter ikke skal fremstå som gjengjeldelse for den $\emptyset$ konomiske støtten som mottas. I tillegg kan forhold som helse, funksjonsevne, omsorgsoppgaver, samvittighets- eller religiøse grunner være av en slik art at den arbeidsrettede aktiviteten ikke er hensiktsmessig for den enkelte stønadsmottakeren. ${ }^{28}$ Komiteen understreker dessuten at en reduksjon eller stopp av sosialhjelp bare kan være i samsvar med sosialcharteret når den ikke fratar enkeltindividet livsgrunnlaget.

Den europeiske menneskerettskonvensjonen (EMK) har ingen konkrete bestemmelser som dekker retten til arbeid eller sosialhjelp. ${ }^{29}$ Den europeiske menneskerettsdomstol (EMD) har ikke behandlet spørsmål om hvilke aktiviteter som kan anses for å være hensiktsmessige som vilkår for utbetaling av sosialhjelp. Imidlertid har domstolen i Schuitemaker mot Nederland (EMD 2010-15906/08) uttalt at i forbindelse med utbetaling av arbeidsledighetstrygd har medlemsstatene en vid skjønnsmargin i økonomisk politikk og sosialpolitikk, deriblant å kunne fastsette hvilke kriterier som skal gjelde for hvem som kan motta trygdeytelser. ${ }^{30}$ Det er rimelig å anta at denne vide skjønnsmarginen i forbindelse med trygderettigheter, også vil gjelde for hvilke kriterier som skal gjelde for mottak av sosialhjelp.

Til tross for nasjonalstatenes nokså vide skjønnsmargin når det gjelder utforming av normer knyttet til sosialhjelp og trygderettigheter, eksisterer det også retningslinjer som den nasjonale skjønnsmarginen bør forholde seg til. FNs arbeidsorganisasjon, ILO, kom i 2012 med anbefalinger knyttet til nasjonale sosiale sikkerhetssystemer, den såkalte ILO Recommendation 202 concerning national floors of social protection. Anbefalingen understreker i punkt 3 bokstav $\mathrm{f}$ at statene bør vise «respect for the rights and dignity of

\footnotetext{
${ }^{27}$ European Committee of Social Rights, ESCR, Digest 12/2008 s. 98. Trine Eidsvaag, «The activation line in social security and social assistance law: a human rights perspective», i Juridification and Social Citizenship in the Welfare State. Glos 2014 s. 81-101, s. 94.

${ }^{28}$ Eidsvaag 2014 s. 94.

${ }^{29}$ Noen av trygdeytelsene kan falle inn under retten til å nyte sin eiendom i fred, jf. EMK første tilleggsprotokoll art. 1. Gómez Heredo. Social Security, Protection at the International Level and Development in Europe, Strasbourg: Council of Europe Publishing 2009, s. $208 \mathrm{ff}$.

${ }^{30}$ Eidsvaag 2014 s. 84. EMD: Schuitemaker vs. The Netherlands, 4. mai 2010. Saken gjaldt spørsmål om kravet om å ta imot tilbud om arbeid, er en krenkelse av forbud mot tvangsarbeid etter EMK art. 4.
} 
people covered by the social security guarantees» $\mathrm{i}$ etableringen og under opprettholdelsen av det nasjonale sosiale sikkerhetssystemet. ${ }^{31}$

\section{Hvordan kan tilbud og pålegg av aktiviteter fremme eller hemme sosialhjelpsmottakeres overgang til arbeid?}

\subsection{Tilstrekkelig og hensiktsmessig aktivitetstilbud}

Samtlige informanter i vår unders $\varnothing$ kelse beskriver at arbeidspraksis i både ordinære bedrifter og gjennom opplæringsbedrifter med oppfølging fra Nav i stor grad fungerer etter hensikten. I tillegg anvendes ulike lavterskeltilbud, herunder arbeid med bistand og deltakelse $\mathrm{i}$ opplæringsbedrifter som også bistår Nav med å kartlegge den enkelte deltakers muligheter i arbeidslivet. Nav tilbyr kvalifiserende kurs (eks. vekterkurs, truckførerbevis, assistent) der det er hensiktsmessig og mulig, og også jobbsøkerkurs for personer som har behov for det.

Å ha tilstrekkelig med aktivitetstilbud som er hensiktsmessige i forhold til formålene og den enkelte persons behov, er en utfordring flere saksbehandlere trekker frem. Noen av de mindre kommunene i Nord-Norge har samarbeid innad i Nav, slik at sosialtjenesten kan anvende de aktivitetstilbud som er organisert av arbeidsformidlings- og trygdesida. Samtidig har mindre kommuner færre tilbud på grunn av kommunestørrelsen. En informant ønsker seg en «bank» av mulige praksisplasser, og i to mindre kommuner fortalte saksbehandlere at de arbeider målrettet for å ha en slik «bank». Samtidig beskrev saksbehandlerne flere eksempler på utfordringer i rekrutteringsarbeidet, herunder; «vi starter en ringerunde; kan noen ta imot?», «vi har tiltak, men vi mangler praksisplasser», «alle kan jo ikke være på vernet bedrift, majoriteten hører ikke hjemme der», og «vi har tiltak og virkemidler og adgang til å stille vilkår, så jeg ser mer og mer hvor meningsløst det blir så lenge de i arbeidslivet ikke er pliktig til å samarbeide med oss».

Når det gjelder antall ulike aktiviteter tilgjengelig, gir informantene i Stor-Oslo uttrykk for at det finnes lavterskeltilbud, jobbsøkertilbud, samt hensiktsmessige statlige kurs. I tillegg brukes praksisplasser i både det ordinære, lokale arbeidslivet og praksisplasser i skjermede bedrifter. Enkelte Nav-kontorer tilbyr også praksis i eget hus, som for eksempel i husets kantine. Lavterskeltilbudene er enten kommune- eller bydelsstyrt, og noen bruker også

\footnotetext{
${ }^{31}$ ILO - Social Protection Floors Recommendation, 2012 (No. 202) - Recommendation concerning National Floors of Social Protection Adoption: Geneva, 101st ILC session, 14. juni 2012.
} 
eksterne samarbeidspartnere for dette tilbudet. Informantene fra Stor-Oslo har med andre ord ikke gitt uttrykk for at det ikke finnes nok aktiviteter å drøfte og se nærmere på sammen med stønadsmottakeren. I de mindre kommunene i Nord-Norge har derimot enkelte informanter gitt uttrykk for at kommunestørrelsen begrenser tilgang til aktivitetstilbud.

Høringsinstansen viser bekymring over at plikten til å stille arbeidsrettet aktivitet som et vilkår medfører at det må etableres arbeidsrettede tiltak i kommunal regi, noe som vil kreve $\emptyset$ kte ressurser og kostnader. Det er med andre ord i praksisfeltet en bekymring over at det per i dag ikke finnes nok aktiviteter å pålegge; aktiviteter som oppfyller kravet om å være hensiktsmessige. Det ligger etter kommunenes syn en utfordring i for lavt antall av aktiviteter. $^{32}$

I innstillingen fra arbeids- og sosialkomiteen om endringer i arbeidsmiljøloven og sosialtjenesteloven $^{33}$ gir regjeringspartienes flertall i komiteen kommunene i oppdrag å etablere eller opprettholde aktivitetstilbudet gjennom ulike løsninger som kommunene kan finne frem til ved bruk av lokale fortolkninger og gjennomføringsmetoder. Det antas at komiteens flertall sikter til at Nav lokalt i kommunene kjenner til arbeidsmarkedet og hvilke kommunale arbeidsrettede tiltak som kan etableres eller opprettholdes for å kunne ha tilgang til tilstrekkelige og hensiktsmessige aktiviteter i kommunen. Mindretallet i komiteen understreker at for at en slik aktivitetsplikt skal kunne fungere, må det økte ressurser til for at denne plikten blir et hensiktsmessig virkemiddel. I Prop. 39 L (2014-2015) understrekes at unntak fra deltakelse i aktivitet ikke vil kunne begrunnes med at kommunen ikke har et egnet aktivitetstilbud. Manglende aktivitetstilbud kan kun gjelde som et unntak fra aktivitetsplikten der kommunen ikke rimeligvis kan forventes å ha et egnet tilbud fordi den enkelte har særlige behov for tilrettelegging. ${ }^{34}$ Det understrekes videre at en lovpålagt plikt til aktivitet ikke skal gis uten begrunnelse $\mathrm{i}$ at dette er en hensiktsmessig aktivitet. ${ }^{35}$

Valgmulighet blant flere aktiviteter nettopp for å finne den hensiktsmessige aktiviteten er en større utfordring for de mindre kommuner, slik en informant i nord beskriver:

«Det er mye tyngre nå å finne praksisplasser enn tidligere, bruker mer tid...men vi har også tyngre brukere nå enn før, de krever mer...og da kreves jo mer av

\footnotetext{
32 Prop. 39 L (2014-2015) pkt. 6.5.

${ }^{33}$ Innst. 208 L. (2014-2015), Adgang til midlertidig ansettelse mv. og vilkår om aktivitet for stønad til livsopphold. Flertallets merknader i arbeids- og sosialkomiteen, punkt 4.14.

${ }^{34}$ Prop. 39 L (2014-2015) pkt. 6.6.3.

35 Op. cit. pkt. 6.6.2.
} 
arbeidsplassene også...jeg synes det er vanskeligere nå enn før å finne plasser. Mer kompleks enn før. Liten kommune.»

Fortellingene fra informantene viser at kontakten til det lokale arbeidsmarkedet allerede i dag krever en stor grad av oppfølgingsinnsats og dermed ressurser. $\AA$ ha tilstrekkelig med aktivitetstilbud er en utfordring, spesielt for de mindre kommunene. Videre fremheves viktigheten av at aktiviteter ikke må tilbys eller pålegges for aktivitetens skyld, men ha mål og mening i forhold til målet om arbeid og mestring. Det er også et tankekors at Nav er forpliktet til å ha et tilstrekkelig antall ulike aktiviteter å tilby, når arbeidslivet på sin side ikke forpliktes til å ta imot sosialhjelpsmottakere i praksis.

At aktiviteter skal være hensiktsmessige er informantene generelt opptatt av.

Aktivitetstilbudet må ifølge informantene passe for den enkelte stønadsmottakeren, og kunne lede til det flere av dem omtaler som «det langsiktige målet» om inkludering i ordinært arbeidsliv og dermed «sjølforsørging». Flere informanter påpeker viktigheten av å finne «riktig aktivitet». En informant uttalte at han/hun ikke oppfatter seg forpliktet til å «tilby en aktivitet for aktivitetens skyld», men at aktivitetstilbudet var et resultat av oppfølgingsarbeidet. En annen informant uttrykte at den valgte aktiviteten må være det som «trengs for at folk skal komme videre».

Våre informanters begrunnelser er basert på någjeldende ordlyd i sostl $§ 20$. I forarbeidene til sosialtjenesteloven 1991 om adgangen til å stille vilkår for tildeling av økonomisk sosialhjelp, uttales: «Særlig aktuelt vil det være å stille vilkår om at arbeidsløs ungdom med problemer på arbeidsmarkedet skal gjennomgå arbeidstreningskurs eller annen nødvendig opplæring som kan medføre at de kommer i vanlig arbeid». ${ }^{36}$ Ut fra dette er det tydelig at sosialtjenesten blir gitt slik adgang for å kunne bistå de unge sosialhjelpsmottakere med arbeidsrettede tiltak, og at aktivitetene skal kunne pålegges dersom det ble vurdert som hensiktsmessig og nødvendig.

I departementets høringsforslag til den fremtidige sostl. § 20 defineres aktivitetene som «aktiviteter med sikte på overgang til ordinært arbeid eller utdanning», og at aktivitetene kan være kommunale tiltak, statlige tiltak eller tiltak i samarbeid med tiltaksleverandører, sosiale entreprenører, utdanningsinstitusjoner eller andre. ${ }^{37}$ Aktivitetstilbudet vil kunne omfatte såkalte lavterskel aktivitetstiltak som vil kunne pålegges stønadsmottakere med utfordringer 
og behov som medfører at målet om arbeid ligger mer frem i tid. Andre aktiviteter vil være klart målrettede og konkrete arbeidsrettede aktiviteter for personer som har arbeidsevne, men som har behov for å vedlikeholde sin kompetanse i påvente av et egnet arbeidstilbud. Departementet understreker at mellom disse to ytterpunktene vil det være behov for ulike grader av tilrettelagte kompetansehevende aktivitetstilbud. ${ }^{38}$

I kravet om hensiktsmessig aktivitetstilbud ligger det dermed to elementer; tilbudet må være egnet til å styrke stønadsmottakerens muligheter for arbeid, og det må være tilpasset den enkeltes funksjonsnivå. ${ }^{39}$ En sentral forutsetning for å kunne pålegge et hensiktsmessig aktivitetstilbud er at saksbehandleren kan velge mellom ulike arbeidsrettede aktiviteter og et utvidet tiltaksapparat. Variasjonsbredden av aktiviteter vil kunne bidra til at vilkåret om aktivitet er tilpasset mest mulig den enkeltes behov og funksjonsnivå, og dermed styrke både personens motivasjon og mulighet for arbeid på kort eller lang sikt. En slik variasjonsbredde krever enten økte ressurser eller en omdisponering av eksisterende ressurser ved de lokale Nav-kontorer. Det understrekes derfor at en universell aktivitetsplikt fordrer tilstrekkelig tilgang til hensiktsmessige aktivitetstilbud for å bidra til overgangen fra sosialhjelp til arbeid.

\subsection{Forsvarlige utredninger}

For å sikre at aktiviteten er tilpasset den enkelte persons livssituasjon og forutsetninger forutsetter lovforarbeidene at saksbehandlerne i Nav foretar en individuell vurdering (se nærmere del 5.1), En slik individuell vurdering av individets behov, ressurser, synspunkter og $\emptyset$ nsker krever at saksbehandleren foretar en kartlegging og vurdering.

Individuell kartlegging og vurdering er et tema som trekkes frem av informantene i vår undersøkelse. En informant forteller at det i løpet av første måned gjøres en grundig kartlegging. En annen forklarer:

«Blant våre ungdommer er det så mange som sliter med mange ting, og da må kanskje litt tid gå, til kartlegging og samtaler før de kan begynne på aktiv ungdom om kanskje en måned. Litt avhengig av hva vedkommende sier i første, andre, tredje møte. Så sier kanskje vedkommende at de ikke klarer. Da må vi gå en annen vei.»

At individuell kartlegging kan kreve tid fremheves av flere informanter. Tiden må ikke bare brukes for å finne den eller de rette aktivitet(ene), men også ta hensyn til stønadsmottakerens

\footnotetext{
${ }^{38}$ Op. cit. pkt. 6.6.2.

${ }^{39}$ Se også Prop. 39 L (2014-2015) pkt. 6.6.2.
} 
motivasjon; «Vi må ikke skremme dem bort, ved at vi rusher på. Det er jo målet vi skal jobbe etter, men for noen er det for mye. Da ødelegger vi en grunnpilar og så blir de borte for oss.» Tid for flere samtaler, og da sannsynligvis også tid for en grundig kartlegging, som et sentralt moment for å skape en mer varig relasjon til de unge voksne, fremheves også av denne informanten:

«Jeg tenker at det tar litt lenger tid enn én samtale for å finne noe som matcher. Om ungdommen selv ikke har en hel åpenbar mening om det selv. Fordi mange av de jeg snakker med, de vet ikke helt hva de klarer, kan eller hva de vil. Og da kreves det tid for å opparbeide en sånn relasjon før man kanskje kan komme på banen til å i det hele tatt finne ut hvilke ressurser og hvilke hindringer som finnes der.»

Informantenes beskrivelser kan sees i sammenheng med sosialtjenestelovens (2009) individperspektiv, forsvarlighetskrav og krav til forholdsmessighet. Individperspektivet er synlig allerede i formålsbestemmelsen $§ 1$; «Den enkelte» skal få mulighet til et selvstendig liv. Økonomisk stønad bør ta sikte på å gjøre «vedkommende» selvhjulpen, jf. sostl. § 18 andre ledd, og sosialtjenestens tjenestetilbud må så langt som mulig utformes «i samarbeid med tjenestemottaker», «tilpasset den enkeltes..[..]..behov jf. Nav-loven $\S \S 1$ og 15 andre ledd, samt sostl. $§ 42$. Forsvarlighetskravet i sostl. $\S 4$ beskrives ikke nærmere i loven, men ifølge lov 10. februar 1967 om behandlingsmåten i forvaltningssaker (forvaltningsloven, fvl.) $\S 17$ skal alle saker være så godt opplyst som mulig før vedtak treffes, og Nav må derfor samarbeide med tjenestemottakeren slik at tjenestetilbudet blir tilpasset hans/hennes ressurser og behov. Kartlegging og tillitsbygging i enkeltsaker samt anvendelse (og videreutvikling) av den enkelte persons egen motivasjon er nødvendige faktorer for å kunne nå målene for den enkelte. ${ }^{40}$ Disse faktorene er derfor nødvendige når Nav skal oppfylle lovens formål i den enkelte sosialhjelpssak.

Kravet til forholdsmessighet vises i sostl. § 20 før lovendringen ved at en person kan pålegges å utføre «passende arbeidsoppgaver i bostedskommunen», dersom aktiviteten har «nær sammenheng med vedtaket» om økonomisk sosialhjelp og aktivitetsplikten ikke var «uforholdsmessig» byrdefull for vedkommende person. Det skjønnsmessige begrepet «uforholdsmessig» innebærer at de pålagte aktiviteter ikke skulle være mer enn vedkommende kunne mestre. I tillegg legger ordlyden opp til et krav om en forholdsmessighet mellom lovens formål om økonomisk og sosial trygghet, selvstendighet og

\footnotetext{
${ }^{40}$ Aina A. Kane 2013 s. 241.
} 
overgang til arbeid for vedkommende, og de aktiviteter han/hun skulle bli pålagt. A delta i hensiktsmessige arbeidsrettede aktiviteter som for eksempel arbeidspraksis eller jobbsøkerkurs ville derfor kunne betraktes som forholdsmessige for en arbeidsledig og arbeidsfør person, hvor aktivitetenes mengde og innhold tilpasses den enkeltes ressurser, begrensninger og behov. Forsvarlighetskravet i sostl. § 4 lest i sammenheng med vektlegging av individperspektivet i sostl. $\S \S 1,18,20 \mathrm{og} 42 \mathrm{og}$ forholdsmessighetskravet i någjeldende sostl. $\S 20$ taler sterkt for at saksbehandleren må kartlegge søkerens livssituasjon og utforme et vedtak med tilhørende vilkår i henhold til enkeltindividets situasjon.

Individperspektivet knyttet til sosialstønad og tilhørende vilkår om aktivitet (se punkt 3.2), tilsier også at det må foretas en individuell vurdering av om det skal stilles vilkår om aktivitet, og i tilfelle hvilken aktivitet, eventuelt hvorfor det ikke skal stilles aktivitetskrav.

En informant som jobbet i mottaksavdeling i en større kommune, forklarte at de først gjennomfører én rådgivings- og veiledningssamtale, hvor tidligere erfaringer kartlegges samt hvor søkeren befinner seg akkurat nå med tanke på arbeid, utdanning og helse. Enkelte informanter beskrev arbeidsmåter der søkeren dagen etter første samtale blir pålagt å møte opp på et lavterskeltilbud av arbeidsrettet aktivitet. Ungdommen får der beskjed om «...å møte opp der med en gang, hvis ikke făr dem ikke penger». En annen informant uttaler at «vi her er så heldig at vi har et tilbud hvor vi kan henvise folk på dagen, eller gjerne neste dag» mens en annen sier at «...det er raskt til disse tiltakene vi har...». Med ett unntak kommer uttalelsene om oppmøte på lavterskeltilbudet dagen etter fra informanter som er ansatt i større kommuner. Disse kommunene har denne typen arbeidsrettede aktivitet for alle søkere som ikke passer til andre arbeidsrettede tiltak som arbeidsavklaringspenger, kvalifiseringsprogram eller ordinære praksisplasser. Uttalelsene gir inntrykk av at med mindre det finnes kjente helseutfordringer og en legeerklæring kan forevises, blir lavterskeltilbudet det vilkåret som knyttes til vedtaket om økonomisk stønad.

Ved Nav-kontorer med tilgjengelige laveterskeltilbud ga saksbehandlerne inntrykk av at den arbeidsrettede aktiviteten representerer en mulighet for avklaring av stønadsmottakerens ressurser og utfordringer. Den første individuelle vurderingen og kartleggingen får altså en forholdsvis rask behandling i et første mottaksmøte. Tiden for å skape en trygg relasjon med den unge voksne skjer i fasen der avklaringen under den arbeidsrettede aktiviteten skjer. En informant sier følgende: 
«...jeg tenker jo at med disse tiltakene, er jo det viktigste, det er avklaringen, det er ikke tiltaket i seg selv som er hovedgreia. Det er avklaringen. Er det noen hindringer man ikke har sett før?».

Disse saksbehandlerne beskrev at deltakelse i aktivitet ikke bare var et mål, men også et middel for å kunne avklare muligheter og ressurser. Dette er en tankegang som også beskrives av Øystein Spjelkavik gjennom tilnærmingsmåtene «place then train» heller enn «train then place». ${ }^{41}$ «Place then train» - først plassering - så opplæring, innebærer å bruke det ordinære arbeidslivet som middel og mål, og det krever ifølge Spjelkavik «inkluderingskompetanse». ${ }^{42}$ Slik inkluderingskompetanse omfatter adekvate og relevante kunnskaper om brukeres behov, om hvordan arbeidsplasser kan brukes for den enkelte brukers utvikling, samt om arbeidsmarked og arbeidsmuligheter i lokalmiljøet. «De som har store bistandsbehov for å komme i jobb, øver og utvikler seg med bedre effekt på vanlige arbeidsplasser enn på treningsarenaer utenfor arbeidslivet». ${ }^{43}$ Dette står i motsetning til å bruke en tilnærming hvor all kartlegging, opprustning og utvikling skjer utenfor arbeidslivet, ut fra tanken om at personer må «klargjøres» før de kan plasseres på en arbeidsplass/praksisplass.

Hvilke krav lovgiveren stiller med tanke på innsats og tidsbruk innenfor «individuell vurdering» av den enkelte søkers situasjon er ikke omtalt i forarbeidene til endringsloven. Det kan stilles spørsmål ved om plassering i aktivitet dagen etter det første møtet mellom saksbehandleren og stønadsmottakeren, med påfølgende avklaring, på en god nok måte ivaretar behovet for endringsarbeid for å få den unge voksne inn i arbeidslivet eller tilbake til utdanning. For mange unge sosialhjelpsmottakere vil tid være nødvendig både for problemavklaring og for opparbeidelse av tillit, da deres problemer kan være dyptgripende og diffuse og derfor vanskelig å avdekke tidlig. ${ }^{44}$ Forfatteren peker her på at vanskelige oppvekstforhold samt fysiske og psykiske helseproblemer er fellestrekk hos mange unge sosialhjelpsmottakere, og at underdiagnostisering og skjult problematikk hos sosialhjelpsmottakerne er en sentral utfordring når disse skal fokusere på arbeid. ${ }^{45}$ Den snevre unntaksadgangen i den fremtidige sostl. $§ 20$ første ledd kan føre til at flere unge voksne vil

\footnotetext{
${ }^{41} \emptyset y$ stein Spjelkavik, «Ordinært arbeidsliv som metode og mål», i Inkluderingskompetanse - ordinært arbeid som mål og middel. Oslo 2014 s. 33-49, s. 33.

${ }^{42}$ Spjelkavik 2014 s. 37.

43 ibid.

${ }^{44}$ Kristin Reichborn-Kjennerud, «Unge sosialhjelpsmottakere - utenfor og umotiverte?» i Nav ved et veiskille Organisasjonsendring som velferdsreform, Oslo 2011 s. 106-126, s. 119.

${ }^{45}$ Ibid s. 116-119.
} 
kunne oppleve at de mislykkes når de blir pålagt å delta på et lavterskeltilbud og ikke klarer å gjennomføre dette. En informant uttaler seg om dette på denne måten:

«Vi tvinger ikke noen der vi ser at de ikke er klare... Vedkommende må først få en viss følelse av at de vil klare det vi krever, mange av dem har jo erfaringer med nederlag, på nederlag, på nederlag, de får ikke til.»

En tilnærming der arbeidss økere med omfattende bistandsbehov skal delta i ordinært arbeid nokså umiddelbart, forutsetter dermed kunnskap og dyktighet for å unngå å utsette personene for opplevelsen av nederlag på nederlag. De ansatte på Nav-kontoret må inneha og omsette sosialfaglig, helsefaglig og pedagogisk kunnskap om stønadsmottakerens støttebehov og relevant veiledningsmetodikk. I tillegg kreves kunnskap om hvordan ordinære arbeidsplasser kan brukes for at mennesker med omfattende st $\varnothing$ ttebehov skal få og utvikle seg i jobb. ${ }^{46}$ Forsvarlig aktivitetsplikt fordrer således særlig forsvarlige individuelle utredninger.

\subsection{Aktiv og tilpasset oppfølging}

En informant peker på at i de tilfellene saksbehandleren og brukeren ikke umiddelbart finner den hensiktsmessige aktivitet, så må de «noen ganger prøve helt andre ting» og dette «krever mer». Oppfølgingen kan også bli nødvendig der prosessen er annerledes enn forutsett, eksempelvis slik en informant forteller:

«Folk vil gjerne, både av høflighet og...vil gjøre ting, så erfarer vi at det var ikke så optimistisk som vi først tenkte. Jeg erfarer ofte i samtale at folk kan virke både optimistisk og motivert, men i neste runde er det ikke slik.»

Dette medfører, også ifølge denne informanten, at det blir en lengre prosess å få den enkelte ut i ordinær arbeid. I de situasjonene der aktiviteten ikke blir hensiktsmessig fra første stund eller der motivasjonen for å gjennomføre aktiviteten synker, vil oppfølgingsarbeidet måtte være tett på stønadsmottakeren. Behovsvurderingen må således være riktig, for ellers blir «heller ikke bistanden riktig», som en informant uttalte.

Gjennom intervjuene har vi et klart inntrykk av at nettopp de ungdommene som søker sosialhjelp, er de som trenger tettere oppfølging uansett om det er mulig å tilby vedkommende en aktivitet neste morgen. En informant beskriver bydelens lavterskeltilbud som

\footnotetext{
${ }^{46}$ Spjelkavik 2014 s. 39-40.
} 
«et prosjekt for ungdom som kanskje ikke helt vet hva de vil, som ikke er helt i den gruppa som anses som ordinære arbeidssøkere, som kan komme seg raskt ut i jobb, men som trenger tettere oppfølging.»

Selv med et hensiktsmessig aktivitetstilbud trenger disse sosialhjelpsmottakerne forholdsvis tett oppfølging, også for å kunne avklare behov og ønsker. Informantene forteller om ulike former og kvalitet av oppfølging, hvor saksbehandleren sammen med unge stønadsmottakere setter opp en plan som av flere benevnes som aktivitetsplan. I tillegg besøker noen Navkontorer sine brukere ute på arbeidspraksis. De som ikke anses som ordinære arbeidssøkere, og som har såpass utfordringer at lavterskeltilbudet anses som mest hensiktsmessig aktivitet, krever tettere oppfølging. En informant beskrev det slik:

«Så hvis det ikke fungerer, så er det en avklaring også... Da prøver vi noe annet. Det er kultur i huset, vi gir oss ikke, og da kan vi av og til tenke, hva i all verden skal vi finne på nå, men da kan det jo være at ukentlige møter, bare kvarter eller tjue minutter er det som trengs akkurat nå.».

Samlet sett viser datamaterialet at det allerede før lovendringen ble gjort mye og tett oppfølgingsarbeid. Saksbehandlerne har søkt og søker etter mulige veier for å oppfylle sitt mandat om å få stønadsmottakere i arbeid og til å bli økonomisk selvhjulpne.

Aktivitetsplikten slik den nå er lovfestet, vil altså etter all sannsynlighet ikke øke ressursbruken i de Nav-kontorene som allerede før lovendringen har hatt som hovedregel å stille aktiviteter som vilkår for mottak av økonomisk stønad med hjemmel i någjeldende sostl. $\S 20$. De kommunene som imidlertid hittil ikke har stilt aktivitet som vilkår, vil oppleve et behov for bruk av økte ressurser på grunn av behovet å følge opp den enkelte som er i aktivitet. ${ }^{47}$ Behovet for $\varnothing$ kte ressurser henger også sammen med behovet for å sikre at den pålagte aktiviteten ikke fører til et nytt tap av mestring, se ovenfor punkt 5.2. Saksbehandleren på Nav-kontoret må ha mulighet til å anvende sosialfaglig, helsefaglig og pedagogisk inkluderingskompetanse.

Det er her relevant å trekke inn de gode resultatene fra kommunene Fjell og Åmli (se punkt 1), resultater som kommunene begrunnet nettopp i sitt fokus på tett oppfølging - innenfor

\footnotetext{
${ }^{47}$ Prop. 39 L (2014-2015) pkt. 6.1.
} 
rammene av sostl. $\S 20$ slik den er før lovendringen. Aktivitetsplikten fordrer aktiv og tilpasset oppfølging for å lykkes i målet om å fremme overgangen til arbeid.

\subsection{Tilbud om aktivitet i motsetning til plikt om aktivitet}

For å kunne svare på problemstillingen vår, er det avgjørende å stille spørsmålet om det er aktivitetstilbud eller aktivitetsplikt som fremmer overgang fra sosialhjelp til arbeid.

Vi ba saksbehandlerne beskrive hvordan de formidler til sosialhjelpssøkerne/-mottakerne at de forventes å delta i aktiviteter, og hvordan personene responderer på dette.

Ifølge saksbehandlernes beskrivelser blir deltakelse i aktivitet formidlet i form av et tilbud, kombinert med begrunnelser for hvorfor aktivitetsdeltakelse tilrådes. Saksbehandlernes uttalte blant annet at «Jeg tilbyr tiltak, men forklarer konsekvenser av å ikke ta imot». Videre beskrev de hvordan de orienterte sine søkere, eksempelvis: «Jeg informerer om sosialhjelp, at det er siste mulighet og det forventes at du skal bidra, øke inntekter», «Jeg ville sagt: «nå er det slik at vi har kartlagt deg og vurderer deg egnet for arbeidstiltak så jeg ordner et møte, og jeg kan gjerne bli med deg»». En annen saksbehandler presiserer at «De kan takke ja eller nei, så må vi ta det derfra».

Disse saksbehandlerne var entydige på at sosialhjelpsmottakerne i all hovedsak samtykker til de gitte tilbud. «De reagerer helt fint, de forventer at ja selvfølgelig skal jeg gjøre noe», og «De aller fleste tar det som gitt at de skal, og takker ja», er eksempler på det. En annen nyanserte noe; «Alle samtykker, er det en som mener de ikke kan akkurat nå...vi finner veier». To saksbehandlere fortalte at deres brukere endog uttrykte lettelse og glede over å få et aktivitetstilbud; «De fleste blir glad og er veldig glad for å komme i gang, de ønsker jo det», og «Folk ønsker å være som alle andre. De ønsker å gjøre det som forventes. Folk ønsker å være i jobb, å ha ei inntekt, være selvstendig, de aller fleste har det målet».

På direkte spørsmål svarte informantene i nord at de nesten aldri opplever at sosialhjelpsmottakere nekter å delta i aktiviteter. Noen saksbehandlere poengterer at samtykket kan bli gitt fordi brukeren vet at det uansett forventes. I tillegg kan samtykket stå i misforhold til hva brukeren faktisk er i stand til å gjennomføre; noe som vises i uttalelser som: «Hvor det ligger hen, om de er høflige men egentlig kjenner at «dette klarer jeg ikke eller vil jeg ikke» det vet man ikke», «Noen sier det de tenker du vil høre» og «Mange sier «å så kjempeflott», men når det kommer til stykket så...vi sitter jo med mye makt, det er vi som bestemmer over pengene»». En informant forklarte at «Noen kan bli litt skeptisk i 
begynnelsen, redd...hva er dette, vil jeg kunne klare? Men det handler om å forklare dem, ufarliggjøre».

Ved to av Nav-kontorene i Stor-Oslo forklarer saksbehandlerne til brukerne at de(n) tilbudte aktivitet(er) vil bli satt som et vilkår for utbetaling av stønaden, en ordning som tilsvarer lovforslaget om universell aktivitetsplikt. Saksbehandlerne i nord anvender vilkårsadgangen som en alternativ mulighet dersom personen ikke samtykker eller ikke gjennomfører aktiviteter, noe som vises i uttalelser som: «Jeg kommer kanskje dit, men jeg starter ikke der. Alt etter hvordan jeg vurderer folks ståsted så hvor tidlig jeg stiller krav kommer an på hvordan jeg vurderer hver enkelt person». Denne tilnærmingen uttrykkes også av to andre informanter: «Vi tvinger ikke noen der vi ser at de ikke er klar, på grunn av helse, familie eller at det skjer så mye rundt dem, de må få ryddet opp først», og «Vi stiller vilkår, men noen ganger gjør vi det ikke igjen, hvis de er veldig dårlig motivert...». Det er altså en tendens at informantene stiller vilkår om arbeidsrettet aktivitet, men formidler det til stønadsmottakeren som en mulighet og et begrunnet tilbud og tilpasset stønadsmottakerens behov og ønsker.

En informant beskriver videre at det hensiktsmessige ikke nødvendigvis ligger kun i selve aktiviteten som stilles som vilkår, men også i omfanget den enkeltes plikt;

«jeg har for eksempel latt dem selv bestemme om de vil møte hver dag eller tre dager i uken. For noen av de har ikke gjort noe på veldig lenge og det kan være en brå overgang om man skulle møte opp hver dag.»

Informantenes uttalelser tyder derfor på at overgang fra sosialhjelp til arbeid fremmes av at Nav kan tilby aktivitet(er) som ivaretar sosialhjelpsmottakerens motivasjon og medvirkning. Hvorvidt en universell aktivitetsplikt vil kunne fremme overgang til arbeid på samme måte, gjenstår å se.

\subsection{Den hemmende universelle aktivitetsplikten?}

Vi stiller spørsmålet om den universelle aktivitetsplikten som ligger i lovendringen kan gå på bekostning av de individuelt tilpassede aktivitetstilbud og dermed bidra til å hemme overgangen til arbeid.

Vårt datamateriale viser at saksbehandlerne i Nav vektlegger grundig kartlegging, men at tidspunkt for de ulike deler i kartleggingsprosesser kan variere. Noen Nav-kontorer kartlegger i større grad forut for tilbud om aktivitet, mens enkelte med umiddelbart tilgjengelige lavterskeltilbud, kartlegger underveis. Datamaterialet viste dessuten at mange kommuner har 
presentert arbeidsrettede tiltak som et tilbud i motsetning til et krav, og at de aller fleste sosialhjelpsmottakere både takker ja til tilbudet og gjennomfører. Flere saksbehandlere setter vilkår om aktivitetsdeltakelse først som en konsekvens av motstand eller manglende gjennomføring. Det er derfor betimelig å spørre; hvordan kan en plikt fremme overgangen til arbeid bedre enn en opsjon? Kan plikten i realiteten hemme overgangen?

En universell aktivitetsplikt vil kunne gjøre selve aktiviteten til en plattform og kontekst for Navs videre kartlegging, tilpasning og oppfølging av den enkelte, noe som kan fremskynde overgangen til ordinært arbeidsliv. Ressurser og hindringer kan komme raskere til syne hos personen på arbeidsplassen, noe som kan bidra til mer tilpasset oppfølgingsarbeid. Ifølge Spjelkavik innebærer slik inkluderingskompetanse hos støtteapparatet at «arbeidss $\varnothing$ kere med omfattende bistandsbehov får anledning til å delta i arbeidslivet uten å bli avvist som «ikke jobbklar» eller «ikke ferdig avklart». ${ }^{48}$

Enkelte høringsinstanser har påpekt at dagens lovregulering som muliggjør slike avtaler om arbeidsrettede aktiviteter, er hensiktsmessig og motivasjonsskapende. ${ }^{49}$ Slik den nye lovbestemmelsen er utformet med aktivitetsplikt som hovedregel, blir plikten et tilleggsvilkår for rettskrav på sosialhjelp, siden ordlyden krever tungtveiende grunner for å ikke pålegge plikten. Nav-ansattes plikt til å sette et vilkår om aktivitet til tilnærmet alle sosialhjelpssøkere kan sies å forskyve makt, ved at klienten må tilpasse seg systemet i stedet for at sosialkonsulenten må tilpasse seg klienten. Avmaktopplevelsen kan dermed bli større for klienten, noe som igjen kan lede til minsket motivasjon og mestringsopplevelse for aktivitet og arbeid. Departementet tilbakeviser dette argumentet med at motivasjon uansett vil variere over tid. ${ }^{50}$ Det er her tydelig at departementet forutsetter at aktivitet satt som vilkår er basert i søkerens motivasjon for arbeid.

Enkelte saksbehandlerne, hovedsakelig de som ikke umiddelbart kan tilby lavterskeltilbud, uttrykte imidlertid bekymringer for at en universell plikt vil føre til at mange unge sosialhjelpssøkere blir utsatt for press og situasjoner som påfører dem ytterligere mestringstap. Disse unge er ifølge enkelte informanter allerede en risikoutsatt gruppe, de som sliter med psykiske problemer, som ikke ble fanget opp av hjelpeapparatet, som ikke fikk (tilstrekkelig) hjelp av barnevernet, og mange har falt ut av skolegang allerede i ungdomsskolen. Datamaterialet viser at enkelte saksbehandlere antar at en del av

\footnotetext{
${ }^{48}$ Spjelkavik 2014 s. 41.

${ }^{49}$ Prop. 39 L (2014-2015) pkt. 6.6.2.

${ }^{50}$ Prop. 39 (2014-2015) pkt. 6.6.2.
} 
sosialhjelpsmottakerne samtykker til aktiviteter av ren høflighet og fordi de vet at de må, men at mange ikke klarer å gjennomføre den avtalte aktiviteten. Overgangen til arbeid kan derfor bli hemmet ved at brukere blir for raskt plassert ut i aktiviteter de ikke vil kunne mestre, fordi kartleggingen har vært for overflatisk til å avdekke det. Risikoen kan oppveies av at vedtaket kan omgjøres når saksbehandleren ser at lavterskelaktiviteten ikke passet for stønadsmottakeren, men den eventuelle skaden ved mestringstap, som kan hemme overgangen til arbeid, er imidlertid allerede gjort. For at saksbehandleren skal kunne unngå å måtte tvinge personer ut i nye mestringstap, må fritak fra aktivitetsplikt besluttes gjennom lovens strenge unntaksbestemmelse (se punkt 5.2). Individuelt fritak gjennom en unntaksbestemmelse innebærer en vesentlig forskjell fra individuelt vilkår om aktivitetsplikt. Å tilhøre et unntaksmessig mindretall som ikke klarer aktivitet, kan utløse en ytterligere opplevelse av mestringstap. ${ }^{51}$ Disse dilemmaer gir grunner til å stille spørsmål om aktivitetsplikten i realiteten kan komme til å hemme overgangen til arbeid.

Under punkt 6.6.3 i forarbeidene angående «unntak ved tungtveiende grunner» understrekes igjen at ved enhver søknad til livsopphold skal det foretas en individuell vurdering av om det skal stilles vilkår om aktivitet, herunder om forhold ved stønadsmottakeren eller den situasjonen vedkommende er i tilsier at det ikke skal stilles aktivitetskrav. Det forutsettes videre at med få unntak forpliktes stønadsmottakere til å delta i et tilpasset aktivitetstilbud. ${ }^{52}$ Det foreligger altså så vel en universell som en individuell aktivitetsplikt. Når sosialhjelp er en forholdsvis lav utgift for det offentlige sammenlignet med trygde- og pensjonsytelser (se punkt 2), aktualiseres igjen spørsmålet om hensiktsmessigheten av lovendringen.

Der den universelle aktivitetsplikten ikke møtes med tilstrekkelige og hensiktsmessige aktiviteter samt god oppfølging fra saksbehandleren, vil den kunne føre til stigmatisering av sosialhjelpsmottakere. Å tilhøre den snevre gruppen av mottakere som er omfattet av unntaksbestemmelsen, vil også kunne påføre en opplevelse av skam og mestringstap. I så fall vil den universelle aktivitetsplikten kunne hemme overgangen fra sosialhjelp til arbeid.

\section{Sammenfattende bemerkninger og avsluttende diskusjon}

Vår undersøkelse har i all hovedsak vist at Nav, før lovendringen om universell aktivitetsplikt,

\footnotetext{
${ }^{51}$ For en nærmere diskusjon om stigma, mestringstap og også skam ved å skape forskjeller innen gruppen av sosialhjelpmottakere, se Erika Gubrium, «Not good enough: social assistance and shaming in Norway», i The shame of it - Global perspectives on anti-poverty policies. Bristol 2014 s. 85-110, s. 92, s. 98-100.

${ }^{52}$ Prop. 39 L (2014-2015) pkt. 6.6.3.
} 
- har hatt god erfaring med bruk av arbeidsrettede aktiviteter, herunder arbeidspraksis, men at de ikke har hatt tilstrekkelig antall praksisplasser tilgjengelig,

- har vektlagt at hver avgjørelse om deltakelse i aktivitet må bygge på forsvarlig individuell kartlegging og vurdering, og

- har tilbudt og tilrådet arbeidsrettede aktiviteter fremfor å pålegge slike, og at tjenestemottakere har samtykket og gjennomført.

Videre har saksbehandlerne illustrert at i saker hvor personer ikke har samtykket til eller gjennomført avtalte aktiviteter, er det $\mathrm{i}$ all hovedsak begrunnet i sammensatte problemer hos personene. Disse sammensatte problemer beskrives som diffuse, og handler om sosiale problemer (tilpasningsproblemer, mestringsproblemer) og diffuse psykiske plager som etter saksbehandlernes faglige vurdering har medført at de ikke har vært klare for aktiviteter på det tidspunktet.

Så hvor har skoen trykket? Er det mangel på aktivitetsplikt som har forårsaket at unge sosialhjelpsmottakere har stått uten arbeidsrettede aktiviteter? Vår undersøkelse antyder ikke det, men at det som har manglet har vært tilgang på arbeidsrettede aktiviteter samt ressurser til oppfølging av den enkelte.

Vi stiller også spørsmål om hvorvidt lovteksten er blitt et reelt speil av hva forarbeidene til sosialtjenenesteloven vektlegger. Formålet med å stille vilkår om arbeidsrettet aktivitet skal før lovendringen begrunnes i den angjeldende persons behov for bistand til å komme i arbeid, noe som avspeiles i ordlyden «herunder at mottakeren i stønadsperioden skal utfфre passende arbeidsoppgaver i bostedskommunen». Etter lovendring er ordlyden: det skal stilles vilkår om aktivitet for tildeling av $\phi$ konomisk stфnad med mindre tungtveiende grunner taler mot det». Ordlyden tilsier at det som vektlegges her er at aktivitet pålegges og utføres, heller enn at aktiviteten fremmer overgangen til arbeid. Vårt datamateriale har vist at en hovedfaktor som fremmer overgang til arbeid, er tilgang til tilstrekkelige antall aktiviteter som er hensiktsmessige. Andre hovedfaktorer er fokus på og ressurser til kartlegging og oppfølging av den enkelte, samt fokus på at de unge sosialhjelpsmottakerne er en risikoutsatt gruppe hvor mange har en vanskelig bakgrunn. At lovteksten ikke synliggjør at aktiviteten skal være formålstjenlig for å bistå vedkommende i overgangen til arbeid og selvforsørgelse, kan medføre en uheldig forståelse av hva «aktivitet» kan være. Å pålegge en sosialhjelpsmottaker en aktivitet for aktivitetens skyld som vilkår for å kunne innvilge en søknad om økonomisk sosialhjelp, når grunnvilkårene for stønaden er til stede, vil ikke være i tråd med lovens formål. ESC art. 13 og Grl. § 110 første ledd krever at vilkår som stilles skal bidra til 
tilrettelegging av overgangen til arbeid. Slik tilrettelegging kan etter ESCR kun skje ved å finne frem til hensiktsmessige aktiviteter som fremmer evnen til å skaffe seg sitt eget utkomme. ${ }^{53}$

I tillegg er lovbestemmelsen ombygget på en slik måte at det ikke lenger er aktivitetsplikten som skal vurderes og vedtas, men unntaket. De enkeltstående personer som ikke umiddelbart er i stand til å delta i en aktivitet, vil nå måtte vurderes opp mot en unntaksbestemmelse som krever «tungtveiende grunner», noe som etter vår vurdering kan øke stigmaet rundt en gruppe mennesker som våre informanter beskriver som svært sårbare. Våre informanter har trukket frem utfordringer med å ha tilstrekkelig tilgang til hensiktsmessige aktiviteter å tilby sosialhjelpsmottakere, samt tilstrekkelig ressurser til kartlegging og oppfølging av den enkelte. Dersom disse ressursene ikke er tilstrekkelige etter lovendringen, ser vi muligheten for at personer kan bli unntatt fra aktivitetsplikt på grunn av forhold hos Nav. I så fall vil lovendringen ikke bare være uten effekt, men vil også innebære en forskyvning av ansvar fra Nav til den enkelte sosialhjelpsmottaker som blir unntatt fra aktivitetsplikt på grunnlag av «tungtveiende grunner».

En siste kritikk mot den endrede ordlyden handler om plasseringen av bestemmelsen om den universelle aktivitetsplikten. Sosialtjenesteloven $\S 18$ er en rettighetsbestemmelse, gjennom ordlyden om at den som ikke kan forsørge seg selv «har krav på» økonomisk stønad. Frem til nå har rettighetsaspektet i sostl. $\S 18$ bare blitt innsnevret gjennom adgangen til å sette vilkår i någjeldende sostl. § 20. Nav måtte i hver enkelt sak ta stilling til hvorvidt aktivitet skulle tilbys eller pålegges, og friheten til å sette vilkår var innrammet av de rettslige begrensningene som følger kravene om formålstjenlighet og forholdsmessighet i bestemmelsens andre avsnitt. ${ }^{54}$ Etter lovendringen er deltakelse i aktivitet blitt et lovfestet tilleggsvilkår for å få oppfylt rett til økonomisk stønad, ved at den fremtidige sostl. § 20 sier at det «skal» stilles vilkår om aktivitet. Dette vilkåret er med andre ord en materiell begrensning av retten til stønad som er angitt i sostl. § 18, en begrensning som følger av loven selv, og der det kreves et særskilt vedtak for unntak. En slik begrensning burde fremkommet allerede i det som fremtrer som lovens hovedregel; sostl. $§ 18$.

\footnotetext{
${ }^{53}$ Se ovenfor punkt 4.

${ }^{54}$ Alice Kjellevold, Sosialhjelp på vilkår - Om bruk av vilkår og avtaler ved tildeling av sosiale ytelser, Oslo 1995. Alice Kjellevold, «Bruk av vilkår ved tildeling av sosiale ytelser» i Sosial trygghet og rettssikkerhet. Bergen 1993 s. 113-158.
} 
Overgang til arbeid vil være en mer langvarig og kompleks prosess for noen personer enn for andre. For at aktivitetsrekruttering skal være i tråd med sosialtjenestelovens formål og vilkår, må saksbehandlere også ha tilstrekkelig juridiske kunnskaper. Saksbehandlere i Nav er i stillinger uten krav om spesiell juridisk kompetanse, og det vil rimeligvis påvirke hvilke tolkningsfaktorer de legger til grunn i sitt arbeid. ${ }^{55}$ Dersom Nav over tid utvikler en kultur om at all aktivitet bør være arbeidsaktivitet, er det en fare for at de opprinnelige formålene for arbeidsrettede aktiviteter tapes av syne.

Andreassen og Aars påpeker at Nav-reformen i realiteten ikke ble det som var formålet, og at én av flere grunner er at Nav som organisasjon ikke har maktet å gi den bistand som personer i ulike behovssituasjoner har. «Politikere trekker opp visjoner, men overlater til forvaltningen å operasjonalisere dem». ${ }^{56}$ Sosialhjelpsmottakere er ingen homogen gruppe. Vårt datamateriale viser at disse personene kan ha komplekse problemer i sin livssituasjon, noe som kan sette dem i særlig utsatt risikosituasjon. Grunnloven $\S 110$ pålegger myndighetene å legge forholdene til rette for at personer skal kunne komme i arbeid, og politikerne har i saken om aktivitetsplikt uttrykt en visjon om at plikten i seg selv er den brikken som må legges for at sosialhjelpsmottakere skal komme ut i inntektsgivende arbeid. De ulike Nav-kontorene får nå ansvaret for å operasjonalisere denne plikten, og det gjenstår å se hvorvidt plikten gjør veien fra sosialhjelp til arbeid kortere eller lengre for den enkelte person. Det er en fare for at den vedtatte lovendringen om en universell aktivitetsplikt handler om å ta tak i det som måtte være en antatt manglende vilje hos mottakere av sosialhjelp til å skaffe seg egen inntekt.

Lovendringen synliggjør i langt mindre grad målet om å få tatt i bruk mottakerens evne til å skaffe seg egen inntekt, jf. Grunnloven $§ 110$ første ledd andre setning og menneskerettighetsutvalget om menneskerettigheter i Grunnloven s. 240.

Vår undersøkelse viser at sosialhjelpssøkere/-mottakere i all hovedsak samtykker til de arbeidsrettede aktiviteter som blir tilbudt, så lovendringen om universell aktivitetsplikt kan være hensiktsmessig overfor et forholdsmessig lite antall personer. Det er derfor grunn til å spørre seg om lovendringen kan komme til å koste mer enn den oppnår. Dersom regjeringens hensikt var å stimulere til mer bruk av arbeidsrettede aktiviteter for sosialhjelpsmottakere, kunne en instruks i rundskrivs form vært den korteste og minst stigmatiserende måten å påvirke kommunenes vektlegging av tilgjengelige aktiviteter og bruken av disse. Alternativt

\footnotetext{
55 Aina A. Kane 2015 «Greit at det finnes lover, men det må da vel være lov å bruke skjønn?», i Stat og Styring. Oslo 2015 s. 26-28.

56 Tone Alm Andreassen og Jacob Aars, Den store reformen. Da Nav ble til, Oslo 2015 s. 147.
} 
kunne vi tenke oss en justering av første avsnitt i sostl. § 20 til for eksempel: «Det kan settes vilkår for tildeling av økonomisk stønad. Det skal særlig vurderes om det skal settes som vilkår at mottakeren tar imot tilbud om passende arbeid eller annen aktivitet $\mathrm{i}$ stønadsperioden.»

I tillegg til at lovendringens ordlyd i stor grad kan stigmatisere de mennesker som ikke klarer å gjennomføre en aktivitet på søknadstidspunktet, har den politiske prosessen i forkant av lovendringen også bidratt til stigma gjennom blant annet avisoppslag om «Navere» som «må komme seg opp om morran» ${ }^{57}, \mathrm{og}$ «Sparte millioner på å få de unge opp om morran». ${ }^{58}$ Det er her grunn til å minne om Norges menneskerettslige forpliktelser til å ivareta den enkeltes verdighet i utformingen av vilkår ved sosialhjelp, i tillegg til at vilkårene skal ha som mål å gi varig løsning av sosialhjelpsmottakerens problemer med overgangen til arbeid.

Så til vårt retoriske spørsmål om lovgiveren funnet opp hjulet på nytt, vil vår konklusjon etter dette være at så ikke er tilfelle.

\footnotetext{
${ }^{57} \mathrm{Se}$ http://www.vg.no/nyheter/innenriks/solberg-regjeringen/vil-tvinge-sosialhjelpsmottakere-opp-ommorgenen-fra-nyttaar/a/23263030 [sitert 17.11.2015]

${ }^{58} \mathrm{Se}$ http://www.nrk.no/buskerud/sparte-millioner-pa-a-fa-unge-_opp-om-morran -1.12607442 [sitert 17.11.2015]
} 


\section{Referanser}

Andreassen, Tone A. og Jacob Aars, Den store reformen. Da Nav ble til. Oslo: Universitetsforlaget, 2015

Aasen, Henriette Sinding. Pasientens rett til selvbestemmelse ved medisinsk behandling. Bergen: Fagbokforlaget, 2000

Eckhoff, Thorstein og Jan E. Helgesen. Rettskildelare. 4. utg. Oslo: Tano Aschehoug, 1997 Eidsvaag, Tine (2014), The activation line in social security and social assistance law: A human rights perspective. I: Juridification and Social Citizenship in the Welfare State. Redigert av Henriette Sinding Aasen, Siri Gloppen, Anne-Mette Magnussen og Even Nilssen. Glos, UK: Edwar Elgar, 2014, s. 81-101

EMD-avgjørelse, Lidwina Geertruida Monica Schuitemaker against the Netherlands, Admissibility of application, No. 15906/08, 4. mai 2010

European Committee of Social Rights. Digest of the case law of the Eurpean Committee of Social Rights, 12/2008, 1. september 2008

Gubrium, Erika. Not good enough: social assistance and shaming in Norway. I: The shame of it - Global perspectives on anti-poverty policies. Redigert av Erika Gubrium, Sony Pellissery og Ivar Lødemel. Bristol, UK: Policy Press, 2014, s. 85-110

Frøyland, Kjetil og Øystein Spjelkavik. Inkluderingskompetanse - et integrert perspektiv. I: Inkluderingskompetanse. Ordinært arbeid som mål og middel. Redigert av Kjetil Frøyland og Øystein Spjelkavik. Oslo: Gyldendal Akademisk, 2014, s. 18-31

International Labour Organization (ILO). Social Protection Floors Recommendation no. 202. Recommendation concerning National Floors of Social Protection Adoption: Geneva, 101st ILC session, 14. juni 2012

Innst. O. nr. 9 (1991-1992), Innstilling fra sosialkomiteen om lov om sosiale tjenester mv. (sosialloven). 
Innst. 208 L. (2014-2015), Adgang til midlertidig ansettelse mv. og vilkår om aktivitet for stønad til livsopphold.

Kane, Aina Aune. Godt skjфnn? Vilkår og skjфnnsutфvelse i saker om

arbeidsavklaringspenger og kvalifiseringsstфnad. I: Sosialfaglige utfordringer på nye arenaer

- stemmer fra nord. Redigert av Bente Puntervold B $\emptyset$, Nina Hermansen og Oddbjørg

Stenberg. Stamsund: Orkana forlag, 2013, s. 225-251

Kane, Aina Aune. Greit at det finnes lover, men det må da vel vare lov å bruke skjønn? I: Stat og Styring. Oslo: Universitetsforlaget 2015, s. 26-28

Kjellevold, Alice. Sosialhjelp på vilkår. Om bruk av avtaler ved tildeling av sosiale ytelser. Oslo: Juridisk forlag 1995

Kjellevold, Alice. Bruk av vilkår ved tildeling av sosiale ytelser. I: Sosial trygghet og rettssikkerhet. Bergen: Alma Mater 1995, s. 113-158.

Köhler-Olsen, Julia. Barnets rett til selvbestemmelse i forhold til religiфse normer. Oslo: Det juridiske fakultet, $\mathrm{UiO}, 2012$

Ot.prp. nr. 70 (2006-2007). Om lov om endringer i sosialtjenesteloven og i enkelte andre lover.

Ot.prp. nr. 103 (2008-2009). Om lov om sosiale tjenester i arbeids- og velferdsforvaltningen.

Peczenik, Aleksander. Vad är rätt?. Stockholm: Fritzes, 1995

Prop. 39 L (2014-2015). Endringer i arbeidsmiljøloven og sosialtjenesteloven (adgang til midlertidig ansettelse mv. og vilkår om aktivitet for stønad til livsopphold).

Reichborn-Kjennerud, Kristin. Unge sosialhjelpsmottakere - unge og umotiverte? I: Nav ved et veiskille. Organisasjonsendring som velferdsreform. Redigert av Tone A. Andreassen og Knut Fossestøl. Oslo: Gyldendal Akademisk, 2011, s.106 -126

Spjelkavik, Øystein. Ordincert arbeidsliv som metode og mål. I: Inkluderingskompetanse. Ordinært arbeid som mål og middel. Redigert av Kjetil Frøyland og Øystein Spjelkavik. Oslo: Gyldendal Akademisk, 2014, s. 33-49

Strömholm, Stig. Rätt, rättskällor och rättstillämpning: En lärobok $i$ allmän rättslära. 5. utg. Stockholm: Norstedts Juridik, 1996 